References:

1. Şpar T.V. Prozvişnye antroponimicheskie nominasii v sosiolingvisticheskom aspekte. - Kand. diss. - Ufa, 2012. - $230 \mathrm{~s}$.

2. Superanskaia A.B. Imä cherez veka i strany. - M.: Nauka, 1990. - 190 s.

3. Guznova A.V. Prozvişa kak mikroantroponimy: diferensiälnye priznaki // Baltiski gumanitarnyi jurnal. - 2016. - T. 5. - № 3(16). - s. 36-39.

4. Morozova O.N. Osobenosti internet-komunikasii: opredelenie i svoistva // Vestnik Leningradskogo gos. un-ta im. A.S. Puşkina. № 5. T. 1. Seria Filologia. - 2010. - s.150-157.

5. Kolesnik T.I. Osobenosti funksionirovania lichnyh imen v nemeskoi Internet-komunikasii: leksikosemanticheski aspekt // Aktuälnye voprosy sovremennoi filologii i jurnalistiki. 2018. №4 (31). URL: https://cyberleninka.ru/article/n/osobennosti-funktsionirovaniya-lichnyh-imen-v-nemetskoy-internetkommunikatsii-leksiko-semanticheskiy-aspekt (data obraşenia: 05.12.2020).

6. Gruşina M.V. Gendernyi aspekt sovremennyh nikneimov (na primere otkrytyh chat rumov) // Filologicheskie nauki. Voprosy teorii i praktiki. 2018. №5-1 (83). URL: https://cyberleninka.ru/article/n/gendernyy-aspektsovremennyh-nikneymov-na-primere-otkrytyh-chat-rumov (data obraşenia: 05.12.2020).

7. Anikina T.V. Politizirovannye nikneimy v onomasticheskom prostranstve chatov // Politicheskaia lingvistika. 2011. №1. URL: https://cyberleninka.ru/article/n/politizirovannye-nikneymy-v-onomasticheskom-prostranstvechatov (data obraşenia: 05.12.2020).

МРНТИ 16.31.02 $\quad$ https://doi.org/10.51889/2020-4.1728-7804.26

\author{
Монгилева Н., ${ }^{1}$ Медетова Э. ${ }^{2}$ \\ ${ }^{1,2}$ А. Байтұрсынов атындавы Қостанай мемлекеттік университеті, \\ Қостанай, Қазақстан

\section{КАЗАҚ ЛИНГВОМӘДЕНИЕТІНДЕГІ ОТБАСЫ ҰҒЫМЫНЫН КОСМОГОНИЯЛЫК АРХЕТИПИКАЛЫК БЕЙНЕЛЕРІ}

\begin{abstract}
Аңџдатпа
Отбасы, отбасылық құндылықтар және рулық қатынастар қазақ мәдениетінде ерекше орын алады. Мәдени кодты декодтау қалыптасқан дәстүрлерді, белгілі бір ұлттық дүниетанымнын терең түсінуге мүмкіндік береді. Мақаланың мақсаты - әлемнің, адамның және оның қоршаған ортасының тұтастығы мен біртұтастығы идеясымен сипатталатын қазақтың лингвистикалық мәдениетіндегі “отбасы” лингвистикалық кеңістігін зерттеу. Қазақ мәдениетіндегі лингвистикалық кеңістікке космогониялық архетиптік бейнелер енеді. Жоғарғы күш туралы архитипикалық түсініктер отбасы және оның құрылымы линвоменталды кеңістігінің ішіндегі негізгі лексемаларында сақталынады. Мақалада қазақ мәдениеті әлемінің тілдік бейнесін көрсететін лексемаларға талдау жасалынған, архетиптік бейнеге түсінік берілген. Отбасын белгілеу кезіндегі оттың метафорасы, сонымен қатар кландар тобы туралы өмірлік қуат көзі ретінде идеяларды қалыптастыру сонымен бірге әлемнің космогониялық бейнесінің элементтері болып табылады.
\end{abstract}

Түйін сөздер: мәдени код, архетиптік бейнелер, қазақ тіл мәдениеті, тілдік кеңістік, дискурс

$$
\begin{gathered}
\text { MongilyovaN., }{ }^{1} \text { MedetovaE. } \\
{ }^{2} \\
\text { Kostanay State University A.Baitursynov, } \\
\text { Kostanay Kazakhstan }
\end{gathered}
$$

\title{
COSMOGONIC ARCHETYPICAL IMAGES ON THE FAMILY IN KAZAKH LINGUISTIC CULTURE
}

\section{Abstract}

Family, family values and family relations have a special place in Kazakh culture. Decoding the cultural code gives a deep understanding of the established traditions and linguistic picture of the world of a particular nation. The purpose of the article is to study the linguomental essence/space "family" in the Kazakh linguoculture, which is characterized by the idea of the integrity and unity of the world, man and his environment. The linguistic space of the family in Kazakh culture includes cosmogonic archetypal images. Archetypal ideas about the highest divine power are embodied in the internal form of the key lexemes of the linguistic space of the family and its structure. The article presents an analysis of lexemes reflecting the linguistic picture of the world of Kazakh culture, an interpretation of the archetypal image is given. The metaphorical designation of the family through the semantics of fire, circle, and ancestral relationships determined the cosmogonic linguistic picture of the world

Keywords: cultural code, archetypal characters, Kazakh linguistic culture, linguomental essence/space space, discourse 


\title{
Монгилева Н., ${ }^{1}$ Медетова Э. ${ }^{2}$ \\ ${ }^{1,2}$ Костанайский государственный университет им. А. Байтурсынова, Костанай, Казахстан \\ КОСМОГОНИЧЕСКИЕ АРХЕТИПИЧНЫЕ ОБРАЗЫ В ПРЕДСТАВЛЕНИЯХ О СЕМЬЕ В КАЗАХСКОЙ ЛИНГВОКУЛЬТУРЕ
}

\begin{abstract}
Аннотация
Семья, семейные ценности и родовые связи занимают особое место в казахской культуре. Расшифровка культурного кода дает глубокое понимание сложившихся традиций, картины мира той или иной нации. Цель статьи - изучение лингвоментального пространства "семья" в казахской лингвокультуре, для которой характерно представление о целостности и слитности мира, человека и среды его обитания. Лингвоментальное пространство семья в казахской культуре включает космогонические архетипичные образы. Архетипические представления о высшей божественной силе запечатлены во внутренней форме ключевых лексем лингвоментального пространства семья и его структуре. В статье представлен анализ лексем, отражающих языковую картину мира казахской культуры, дана интерпретация архетипического образа. Метафорическое обозначение семьи через семантику огня, круга, родовых отношений обусловила космогоническую картину мира.
\end{abstract}

Ключевые слова: культурный код, архетипичные образы, казахская лингвокультура, лингвоментальное пространство, дискурс

Кіріспе. Тілдік фактыларды зерттеу барысында, ерекше көңіл белгілі бір лингвомәдениеттің жүйелі құбылыстарын көрсететін заңдылықтарға бөлінеді. Бұндай заңдылықтар В.В.Красных қоршаған әлемді жүйелейтін, категориялайтын және бағалайтын, мәдениеттің “торы” деп түсінетін мәдениет кодын қалыптастырады [1,232б.]. Мәдениет коды ежелгі адамдардың қоршаған орта мен оның сол ортадағы орны туралы архетипикалық бейнелеріне сәйкес келеді. Сонымен қатар зерттеуші, архитипикалық бейнелер-табиғатынан әмбебап феномендер екенін ерекше атап өтеді, дегенмен мәдениет коды туралы оның өзінің білдіруі мен салыстырмалы салмағы бойынша айтуымыз керек [1, 240б.].

Архетип қандай да бір мәңгілік немесе өте ұзақ өмір сүруші константаны білдіреді $[2,846$.$] Константаның$ атынан шыға отырып, архетип адамның дүниеге деген көзқарасының бастапқы моделі болып табылады: бұл бастапқы білім, менталды әлем мен шынайы әлемнің арасындағы “көпір". Архетиптің константтылығы (инварианттылық) оның мәдениетте және әдебиетте өзгерістерінің әртүрлілігін,өзіндік эволюциясын шарттайтын алғашқы модельдің менталды кеңеюін білдіреді [3].

“Архетип” терминін ғылыми қолданысқа енгізе отырып К.Юнг оған бірнеше анықтамалар берген. Оның бірі, архетиптер - бұл репрезентативтік мазмұндағы және біздің білімімізге орталық символдық мағына беретін негізгі мағыналар [4,23б.]. Е.Мелетинский К.Юнгтің теориясын әдеби сюжеттер туралы зерттеу жұмысына қолдана отырып, архетип алғашқы диффузды түрдегі, материалдылық пен мінсіздіктің арасындағы нақты шекарасы жоқ, аңыз шығармашылық ойлау іздерін сақтап қалған деп және ғарыштық кеңістік пен оқиғалар құрылысының изоморфизмімен суреттеледі деп айтып кеткен [5]. Архетип түсінігі бойынша кейбір әмбебап нұсқаулар мен әдеттегі реакциялар “ұжымдық санасыздық” білдіріледі [6]. Ұжымдық санасыздықтағы бейненің алғышарты мен тарихи және ландшафттық шарттағы этноспен біріге отырып құрылып, архетипикалық бейнені құрайды. Архетипикалық бейне инвариант функциясын атқарып, түрлену арқылы әртүрлі лингвомәдени контесттерде қолданылады. Жеке лингвомәдениетте архетипикалық бейне әртүрлі метафоралық бейнелерде іске асырылып, мағынаның мәндік компоненттерінің, тілдік метафоралардың ішкі формасының құрамына кіріп, дискурстық шаблондарда вербаландырылады. Архетипикалық бейне - тілдік даму мен мәдениеттің координаты ретінде қызмет атқаратын, дүниеге деген көзқарастың нәтижесі болып саналатын қандай да бір кескін. Ұлттық мәдениеттің семиотикалық кеңістігі әртүрлі мәдени-тарихи тәжірибеден шығатын, құндылықтар мен мағынадағы айырмашылықтардың (“ажырау”) әсерінен туындаған “аударылмайтын” мағынаны білдіретін архетипикалық сипатқа ие [7].

Мақаланың гипотезасы қазақ лингвомәдениетінде “отбасы” линвоменталды кеңістігінде мәдени константтардың бірі болып, неке ұғымының әлемдік ахуал заңдылығы ретіндегі бейнесін білдіретін космогониялық бейне туралы болжам болып саналады. О.Ю.Берсеновадан кейін линвоменталды кеңістік терминологиясы әрдайым жеке бас ұғымы туралы репрезентациясын табатын және дискурс-универсумда тұрақты вербалды көрініс табатын ойлар, сенім "рух икемі”, бейнелер жиынтығына қатысты теңдік, әділеттілік, міндет түсінігі, жаман мен жақсы категориясы, тарихтың жасалу жолын және т.б. елестетуге қатысты жалпы рухани-мотивациялық этносоциумдағы ұжымдық тілдің икемдігін білдіру үшін қолданылады [8,50б.].

Әдістеме.Қазақ ұлтының дүниеге деген көзқарасының мәдени зерттеу жұмысында олардың көшпенділердің ислам дінінің пайда болуына және олардың дінді қабылдағанға дейінгі болған сенімдерімен байланыстарының барын атап өтеді [9]. Бұл сенім комплексі жердегі өмір мен ғарыштық әлемнің қарым-қатынасына, әр адамның ғарышқа, табиғатқа, басқа адамдарға қатысы болуы туралы ұғымға сүйенген.Көшпенділердің санасында табиғат құбылыстарында адамға ықпал ететін, оның тағдырына жақсы немесе жаман жағынан әсер ететін мәңгілік және түсініксіз күш бар деген түсінік болған $[9,156$.$] . Түрік халықтарының мифологиясы тенгризмнің құрастырушысы$ 
болып есептелетін және түріктердің әлемге деген көзқарасының спецификасын көрсететін бай дүниетанымы бар мәдениеттердің бірі болып табылады [10,14б.]. Тенгризмнің мағыналы категориялық жүйесінің негізгі және түйінді категориясы болып Тенгри есептелінеді. Е.В.Федорова (Тәңри Тәңра, Тәңер, Тәңери, Тәңірі) ғұн және ежелгі түрік тілдерінде тан таң, күн шызу дегенді білдіреді, “жарық барлығын нұрландырады”, “барлығы оянып, өмір сүре бастайды”. “Тэнг” - тең (түрік); якут сөзі танг немесе тангар жсина, құрастыру деген мағынаны береді. “Айыы” сөзіне ұқсас - жаратылыс, жарату, жаратушы, Айыы Тангара табиғаттың, аспанның, ғарыштың, Құрастырушысы, Көсемі, Архитекторы деген мағынаны береді [11,56б.]. Тенгри Рухы әлемді құрастырушы барлық жерде болады, қазақтардың тенгризмі материя деп атайтын материалды монизм, ал идеалистік тенгриізмі ой болып табылады [11,21б.]. Тенгризм мәдениетінінің салттық сипаты түйінді константтарда, Тенгри, Көк, Жол, Жер-Су, Ұмай, Кұт және т.б. қазақтардың мәдени тарихында аса үлкен мәнге ие мифологиялық бейнелерде сақталынып қалған [12]. Мысалы, бұл сөздер заманауи қазақ тілінде қолданысқа ие, тәңір ісі, тәңір жазса, тәңір жарылқап.

Нәтижелер. Отбасы түсінігіндегі жоғарғы күштің архетипикалық бейнесі.

Тенгризмнің ежелгі сенімдері тек отбасылық рәсімдерде ғана (баланың тууы, ат беру рәсімі, үйлену тойы, қайтыс болу т.б.) орын алмайды, дегенмен ислам дінін қабылдағаннан кейін бұрынғы дәстүрлер жойылды, “әдетғұрып пен дәстүрлі табынушылық тұрмыс жағдайына, отбасылық іс-шараларға, адам өмірінің басты сәттеріне ауысты” [13,21б.]. Қазақ халқының туыстық құрылымы бұрыннан әрі кең түрде ғылыми әдебиеттерде берілгенін бірден атап өту қажет [14]. Қазақ халқының туыстық жүйесін егжей-тегжейлі зерттеуден бұрын, оның классификациялы типке жататын айта кету қажет және туыстық термині алты түрге дейін бөлінеді: жыныс, туыстық сипаты (жақ), (қандас немесе жекжаттық), векторлы туыстық түрі (тіке, жақтық, жоғарыдан және төменнен таратылған), туыстық деңгейі (бірінші ұрпақ, екінші және т.б.) туыстық қатынас (ана жағынан, әке жағынан), сөйлеушіге қатысты жас (үлкен, кіші). Тіпті осындай үстіртін туыстық жүйесінің сипаттамасы қазақ отбасының күрделі құрылымды екенін көрсете отырып, әр мүшесінің туыстарына қатысты функциясынының санын көрсетеді. Сондықтан орыс лексемасындағы семья қазақ линвомәдениетіндегі туыстар родственники, родственность мағынасына келеді.

Жоғарғы күш туралы архитипикалық түсініктер отбасы және оның құрылымы линвоменталды кеңістігінің ішіндегі негізгі лексемаларында сақталынады. Көк, (қазіргі қазақ тілінде аспан, көгілдір түс) жоғарғы күш Көк Мәнгі Тәңірі толық атынының бір бөлшегі болып табылады. Көк сөзіндегі жоғары күштің болуы, Көк түрік (аспан түркілері, Аспан Балалары), Көк бөрі (аспан қасқыры, Уран, күш пен табиған әділдігінің белгісі [10,47б.], Көк бұқа аңыз бойынша жерді мүйізінде ұстап тұрған жануар [15,58б.] сияқты мифологиялық кейіпкерлермен дәлелденеді.

Тенгри бейнесі (Көк түсінігіндегі) әкеге және үлкен туыс көкеге (тура аспанға/көкке жеткізу) қаратылып айтылатын лексеманың ішкі формасында сипатталған. Бұл қаратпа сөзді құрмет, махаббат сезімдерін көрсету үшін, бір адамның мәртебесін басқалардын алдында көтеру үшін қолданады. Табиғаттың заңдары мен адам өмірінің заңдарының бірігуі көпмағыналы етістік туу сөзінде беріледі. Бір жағынан бұл лексема ай мен күннің шығысын білдіреді: аспанда ай туды, құйрықты жұлдыз туды, туған ай. Екінші жағынан түбір морфема ту- туыстар, туған жұрт сөздерінде туыстық мағынаны білдіреді.

Заманауи отбасы туралы дискурста Құдайға сілтемелер болады, әсіресе ата-ана жайлы айтылатын болса. Менің де ата-анам бар, Құдайға шүкір; Алла жазса, келесі жылы жастарды бөлек шығармақшымыз; Ал мен ата енеммен бірге турып жаксы келін болгым келеді болашакта кудай каласа; Барлық адам әртүрлі болғанымен, Жаратушымыздың алдында бірдейміз. Бірнеше бірліктердің жоғарғы күш мағынасында (Күдай, Алла, Жаратушы) жұмсалуы қазақ ұлтының санасындағы отбасылық құндылықтардың киелі екенін көрсетеді.

Отбасы лингвоменталды кеңістігінің маңызды лексемаларының бірі - ата. Б.Д. Кокумбаева дәлел ретінде сөзқұраушы тізбекті келтіре отырып, оны басты константа деп атайды: ат - ата - атабек - аталы - атакты - атамекен - атанасия [12]. Ежелгі түрік сөздігінде (ЕTC) ата мағынасынан басқа ат формасында да беріледі [16,64б.]. Демек, туыстық терминдерінің ішкі формасында ата өмір бастауы дегенді білдіріпі, ата- өмір беретін адам. Бірақ заманауи қазақ тілінде ата сөзін білдіру үшін әке немесе көке сөздері қолданылады. Ата, ата-ана құрамдас бөлігінде сақталып, сөйлеушіден алыс ұрпақ ата сөзіне ауысқан (салыст., орыс әлем бейнесінде отец бастапқы мағынасындағы идеяны сақтайды).

Отбасылық лингвоменталды кеңісітігінің ажырамас бөлігі болып аруақтар дүниесінде өмір сүретін аруақтмар болып саналады, қазақтар өздерінің бақ пен сәтсіздіктерін солардың әсерінен болатын деп санайды (аруақ қонған адам). Бұл сонымен қатар отбасы ұғымындағы жоғарғы күштің архетипикалық бейнесінінің бірлесуін көрсетеді. Сәттілік тілегенде аруақтарды шақырады (аруақ саған жар болсын!), аруақтарды қарғыс айтқан кезде де шақырады (аруағынан садаға кет!). Егер көптайпалы орда жиналатын болса, олар ортақ әскери ұрандары Аруақ деп дауыс көтеретін болған [17,52б.].Ұрпақтардың виртуалды байланыстары үйлену той салтында да орын алады: заманауи қазақ тойында аруақтардың батасын алу үшін, аруақтарға арналған кілем төселінеді. Отбасы бейнесіндегі және ежелгі әлем туралы түсінікте бірліктің мысалы ретінде құдалардың мағынасы беріледі - құда, құдағи, құт, достояние, изобилие мағынасын береді. Кұт қазақ мәдениетіндегі және түрік әлеміндегі маңызды константалардың бірі. Кұт жоғарғы игіліктерді білдіретін жеке мағынанада да жұмсалады. Ежелгі түрік сөздігінде Qut сөзінің сипаттамасы екі бетті қамтиды а) жан, өмірлік күш, рух; б) бақыт, игілік, бақ; в) абырой, ұлылық [16,471б.]. Концептуалды түрде құт табиғаттан және рухтан (жоғары күш) бастау алатын өмірлік күш деген мағына береді. Сол сияқты құт Күдай сөзіне енген, мысалы, құдай бұйырса, құдай біледі. Түрік тілдерінің зерттеушісі Н.А.Баскакованың пікірінше, бұл сөз орта түрік дәуірінде (X-XVғғ.) тәжік немесе парсы тілдерінен алтай, қазақ, хакас, татар, ноғай және басқа да түрік 
халықтарымен алынуы мүмкін [18]. Күдала мағынасының құда, құдаzи, құm сөзінен шығуы қалыңдыққа келген кісілердің ерекше дәрежесін көрсетеді. Коммуникативті санада олар ерекше тапсырманы орындаушы, жоғарғы күштердің елшілері екендігін көрсетеді. Неке екі индивидтің бірге тұрып, екі отбасының қарым-қатынас жасауы емес, ол өмірді жалғастырушы діни заңды орындау, екі ұрпақтың қосылуынан шығатын өмірлік күштің дамуының жаңа деңгейі. Көптеген мақал-мәтелдерде некенің құндылығы жастардан (үйленіп жатқан) олардың аға ұрпақтарына ауысады: Күйеу - жүз жылдық, құда - мың жылдық; Досты періште қосады, құданы құдай қосады. Кұдалық лексемасы сонымен қатар дауды шешу жолы туралы мәтелдерінде қолданылады: құда да тыныш, құдағи да разы.

Егер орыс тіліндегі әлем бейнесінде туылу мәні отбасы семья лексемасының шегінде болса, қазақ тілінде бұл мағынаның лексемасы метафоралық бейнедегі қосалқы форма болуы мүмкін (жанұя, отбасы), немесе қосалқы бөлік (үй-іші, үй-күй), метаномиялық өзгерістің нәтижесі болуы мүмкін. Және бұл формалар Ежелгі түрік сөздігі [16] мен Севортянның [19] түрік тілдерінің этимологиялық сөздігіндегі түбірлерден пайда болған ру, тайпа, ұрпақ, ата (рулық қатыс, тайпа, жуз, шежіре, аталар, баба, тектін, төркін, тұқиян), мағыналарымен салыстырғанда өте көп емес. Заманауи қазақ тілінде отбасы мағынасындағы лексемалар басқа мағыналарға ауыспайды (тілдер тобы). Түрік тілдерінің этимологиялық сөздігінде аффикстық алмасу мен өзгерістер заңдылықтары ескерілген заманауи түрік тілдеріндегі түбір сөздің мағынасы беріледі, соның ішінде туыстық мағынадағы түбірлерге ук/uk- (ұк) [19,582б.] жатады. Заманауи қазақ тілінде бұл түбір ұқым-тұқым, ұғым сөзденінің құрамына енеді. Басқа уру:fl uru:ү 1.py 2. тұқым 3. ұрпақ [19,604б.] түбірін талдаған кезде, автор бұл мағыналар түрік тілдерінде семантикалық даму алған бұл форманың басқа мағыналарына қарағанда ең ежелгісі екенін атап көрсетеді және бір семантикалық байланыспен бірігеді. Сөздікте түрік тілдеріне енген yp/ur түбірінен шыққан “ұрықтандыру” және басқа етістігінің нәтижесі мен оның субъекті, объекті аттары мағынасында туындайтын аффикстық формалардың сөздік қатары берілген. Қазақ тіліндегі бұл форманың мысалы ретінде ұрпақ, ұрық сөздерін келтіруге болады. Сонымен қатар түрік сөздігінде туыстық мағынасын беретін екі форма бар: ul және urï. Ul - түбір [16,608б.], заманауи қазақ тіліндегі келесі формаларда сақталған: ұл, ұлт, ұлы. Urï - ұл, urü̈ - ұрпақ, urü̈ özlug - туысқандар мен жакжаттар [16, с. 614], бұл түбірге келесі мысалдар беріледі: ұрпақ, ұрық.

О.Сүлейменов буындарды қайта құрастыру мен алмастрыу заңдарына сүйене отырып ur/ ur, or, ar [20,33б.] - ul ru - [20,42б.] бұл формалар бір праформаның өзгерген түрлері. Рулық топтың мағынасы ру, ру шежіресі, жұрт, рулық сөздерінде беріледі. Мысалдарда берілгендей отбасы лингвоменталды кеңістігінің құрамында тілдік фитоморфтық метафора болғанымен, бұл формалар отбасы лексемасының бөлігі болған жоқ: тұқым; ұрық. Ұрпақ сөзі басқа да метафоралармен көрсетіледі: түлек; үрім-бұтақ. Қазақ халқының менталитетінде ұрпақтың жалғасуы мәңгілік қозғалыспен, өмірдің жалғасуымен байланысты болса, бұл ұл, ұласу, ұлан-байтақ, ұлzайту,ұлан-асыр, ұльл, ұльlс дериваттарының болуын дәлелдейді. Жоғарыда келтірілген мысалдар нуклеарлы отбасыға қарағанда үлкенірек топты немесе сөйлеу субъектісіне қатысты келесі ұрпақты білдіретін лексемаларда сақталған, ал отбасы - рулық топтың бір бөлшегі ғана болып табылады. Omбасы мағыналары туынды болып келеді, демек екінші реттік форма. Сонымен қатар жоғарыда айтылған жанұя, omбасы, үй-іші сөздерінен басқа сөздіктерде отбасы мағынасындағы үйкүй, ошақ қ̧acbl, oшақ бұmbl, omay сөздерін табуға болады. Және де нақышты сөйлемдердің құрамында кездеседі: берекесі жоқ үй. “Отбасы” мағынасында туынды сөздерді шығару барысында көбінесе үй, үйлену шаңырақ, шаңырақ көтеру [тура мағынада, киіз үйді құру барысында шаңырақты көтеру], шаңырағы ортасына түсті [тура мағынада, шанырағы шайқалды], шаңырағың биік болсын[тура мағынада, шаңырақ биікте орналссын] сөз тіркестері қолданылады.

Отбасылық топты білдіру - бұл лексеманың “тұратын жер” семасымен метаномиялық ауысуы: жұрm,oтбасы, omazacb [тура мағынада, оттың үлкен ағасы], жылы орынын суыту [тура мағынада, жылы жерді суытып алу]. Тіпті метафоралық түрде білдіру кезінде де ұя, отбасы, ауысу “тұрғылықты жер” семасы бойынша іске асады. Отбасы мағынасының негізгі семасы болып “тұратын жер” болса, “ұрпақ жалғасы” семасы басқа лексемалардың негізгі ойы болып табылады, жақыналыс туыстар кеңістік метафорасы қазақ дискурсында келесі еркешеліктерге ие: жақын туыстар сөз тіркесі болуы мүмкін, бірақ жақындық критерия болып нуклеарлы отбасы болмайды, сонымен қатар ана жағынан туыстық қатынас (мысалы, әпкесінің баласы жақын деп аталуы мүмкін) немесе қарым-қатынас жасау жиілігі де жатпайды. Аудиторияға жақындар деген сөзді қолданғанда сөйлеуші сол жерде отырғандарды меңзейді. Ауызша дискурста жақын туған сөзіне ауысуы мүмкін. Дегенмен туыстарды бұлай алыс жақын ретінде бөлі негативті түрде қабылдануы мүмкін. Мерекелерде барлығына бейтарап күйде және барлығын қамтитын жалпылама сөздер қолданылады: авайын-жұрт жекжат, авайын, құда-жекжаттар, іні-бауырлар, қарындастар. Алыс туыстықандарға алыс лексемасы орынсыз. Бұндай қатынасты білдіру үшін аталас, авайын, тумалас, жекжат, жекжат-жұрават, сүйек шатыс сөз тіркестері бар. Осындай сөз бірліктерін қолдану “нақты айта алмаймын, дегенмен .... жағынан туысқандар болып келеді” дегенді білдіреді.

Түріктердің ежелгі сенімдері мен көшпенді өмірдің ерекшеліктері, қыста қыстауда тұрған кезде, жазда жайлауда көп ағайындарымен қатынаса өмір сүруі, тұқымның архетипикалық бейнесі және космогонизмнің белгісі ретінде өмірдің бастауы, өмірлік күш беретін таңғажайып қуат көзі екенін анықтаған.

Талқылау. “От" космогониялық бейнесі. Туыстық туралы архетипикалық бейненің нәтижесі ретінде ОТБАСЫ-ОТ/ОШАҚ ОТЫ этномәдени метафораның құралуы болды. Отбасының айнала жиналатын орнының атын ауыстыру көптеген мәдениеттерге дәстүрлі болып келеді. Бірақ қазақ мәдениетінде от жандандыратын қуат, таңғажайып қуаттың бір бөлігі болып саналады. Отқа табыну өте ежелден келе жатқан, үйдегі ошақ отын қорғаушы - Ұмай (Тенгридің келбеттерінің бірі) анаға табынудан шыққан. От әр киіз үйдегі күннің бір бөлігі болып саналған. 
Адамдар отты тұқымның қорғаушысы санаған, сондықтан оны басқа үйдің отымен араластыруға болмайтын [21,168б.]. Om отбасы лексемасының құрамына енеді, сонымен қатар оты өшті тура мағынада, оты сөніп қалды, отын жағу, оты басқаның мұңы басқа тура мағынада, ошақтары әртүрлі, мұңдары да әртүрлі сияқты тұрақты тіркестердің құрамында отбасы мағынасын береді. Отқа табыну қазақ үйлену дәстүрінде де орын алады. Отқа май құю үйге жаңа түскен келіннің отқа құрбан шалуының белгісі.

Отбасының қорғаушысы ретіндегі оттың архетипикалық бейнесі, адамдар арасындағы туыстық қатынасты білдіретін табиғат қуатымен (от, күн, ай) байланысты көптеген сөз тіркестерінде сақталған. Бұл балаларға, кішкентайларға, жақсы көретін жандарға арналып айтылатын сөздер: шылравылм, күнім, жарывым, айналайыл қаравыл, көзімнің нұры. Адардардың ара-қатынасы оттың қуат алмасуымен метафораға айналған. “Басқаларға тартымды болу”, “басқаларға ұнау” мағынасындағы лексемалардың ішкі формасында от бейнесі бар және ол “жарық, от, жылу беру” мағынасын береді, мысалы қылығымен жұртқа жағу, сөзі көңіліме жағып қалды, көңіліне жағу. Келесі мысалда адамның бар жақсы қасиеттері “қуат шашырату” семантикасы арқылы суреттеледі: Абай бойынша, жақсы кісіде үш қасиет: ыстық қайрат, нұрль ақыл және жылы жүрек болу керек делінеді. Жалын бейнелі бағынасында, жалын атау. Жарқын, жаны жарқын адам, ақ жарқын, қадамыңа нұр жаусын.

Таңғажайып куат көзінің архетипикалық бейнесінің түсіндірмесі болып туыстар туралы түсінік өмірлік күштің көзі саналады. Қазақтардың коммуникативтік санасында көпшілік жақсылық, адамның мәртебесі, қолдау ретінде есептелінеді. Ағайын тату болса - ат көп, абысын тату болса - ас көп; Ағасы бардың - жағасы бар, інісі бардың тынысы бар.

“Шеңбер” архетипикалық бейнесі . Шеңбер - қазақ этномәдениетінің ажырамас бөлігі, ол тұрғын үйдің пішіні (киіз үй) және шаңырақтың мәдени белгісі. Шеңбердің сызбасы отбасы мағынасын беруге арналған тілдік бірліктердің қатарына жатады: жанұя - жана ұя, ошақ қасы, ошақ басы, ошақ құру. Үй, ұя, ошақ туынды бірліктері шеңбер пішініне келтіріледі. Ұя, отбасы, туған-туысқан және тәрбие туралы мақал-мәтелдерде өте көп орын алады: Ұяда не көрсең, ұшқанда соны ілесің. Жетесі жаман - тегі нашар, ұшып шыққан ұясы жаман. Үй отбасылық қарымқатынастар туралы үйлі, үйлену семантикалы байланысқан тілдік формаларды құрастыруда қолданылады. Лексикалық бірліктердің қатарына енетін үлгілердің мәдени ерекшеліктерін зерттеу барысында, М.Киммел үлгілер физикалық және әлеуметтік-мәдени қарым-қатынастардың диалектикалық байланыстары арқылы пайда болады деп атап кеткен, сол себепті үлгілер дискурсты, материалды және салттық мәдениетке біріктіріледі [22,298б.]. Қазақтардың мәдениетінде шеңбер бойынша қозғалу ежелгі салттарда бар. Қауіпті сапар алдында отбасымен, туысқандарымен, көршілерімен және ауылымен қоштасу сәтінде спираль бойынша жүріп, ошақ басын айналатын, кейін киіз үй мен ауылды айналып Айналып кетейн!, Айалайын, ауыльлм! Айалайын, атамекен! Айналайын, туван ел! деген жолдарды айтады. Сөйтіп ол жолға шығып және еліне қайтып келісімен бұл салтты үлкеннен кішіге қарай орындайтын болған [23,183б.]. “Біреуге жақсы қарау” мағынасы заманауи қазақ тілінде “объекттің айналасындағы қозғалыс" мағынасымен келтіріледі. Мысалы еркелету мақсатында айалайын айналу сөзінен, айналдыру, сонымен қоса бөлену тіркестері қолданылады. Әр әйел адамның бақыты алдымен отбасын құру, ана атану, отбасының куанышына, мейріміне бөлену. Бөлену етістігі арқылы субъекттің жақсы эмоционалды жағдайын көрсетуге болады: даңққа бөлеу, сый-құрметке бөлеу, бақытқа бөлену. Қазақтардың мифологиясында “шеңбер” архетипикалық бейнесін көрсететін бейне бар. Ол адамды құратын күші бар киелі құс Самрұқтың ұясы. Түріктер мен қазақтар мифологиясының ең танымал желісі ол Самрұқтың балапандарын жегісі келген жыланнан құтқарған Ер Төстік туралы аңыз. Әлем Ағашының биігіндегі Самрұқтың ұясында Ер Төстік қайта туылып, Самрұқтың қанатында жер бетіне оралады. ОТБАСЫ- ҰЯ метафоралары отбасы, туысқандар мен тәрбие туралы мақал-мәтелдерде жиі қолданылады: Ұяда не көрсең, ұшқанда соны ілесің; Құртақандай торғай да, Өз ұясын қорғайды; Жетесі жаман - тегі нашар, ұшып шыққан ұясы жаман; Ұшқан ұя; ұя бұзу; ұя бұзар.

Мифологиялық салттық практикада “шеңбер” белгісін мысалы ретінде тілек мақалды келтіруге болады: Үй болған соң, белбау да керек, желбау да керек. Белбау бұл киіз ұйде сыртынан байлайтын бау, желбау- киіз үйдің ішінде шаңыраққа іліп қоятын шашақ бау. Бұл заттардың негізгі міндеті - қатты дауылдарда киіз үйді ұстап тұру, бұл тіркес отбасының ішкі және сыртқы қиындықтарға төтеп бере алуын білдіреді.

Қорытынды. Қазақ мәдениетіндегі отбасы лингвоменталды кеңістігі құрамына соның арқасында неке арқылы туыстық әлеуметтік қозғалыс ретінде емес әлем құрылымының заңын, жоғарғы күштердің қалауын орындау ретінде қабылданатын космогониялық архетипикалық бейнелерді қосады. Бұл көпшіліктің аксиологиялық құндылығын арттырып, туыстықтың сандық бағасын береді. Әлемнің космогониялық бейнесі отбасы сөзінің метафоралық мағынасын от семантикасы арқылы, ру тайпасын өмірлік куат көзі ретіндегі бейне қалыптастыру арқылы көрсетті.

Пайдаланылван әдебиеттер тізімі:

1 Красных В. В. Этнопсихолингвистика и лингвокультурология: курс лекиии / В. В. Красных. - М. : Гнозис, 2002. - 284 с. - Курс лекичий.

2 Степанов Ю. С. Константы : словарь русской культуры. М., 2001. 824 с. - Словарь.

3 Большакова А.Ю. “Теория архетипа и концептология” Культурологический журнал, по. 1, 2012, рр. 8.Культурологический журнал.

4 Knox, Jean, 2003 Archetype, attachment, analysis: Jungian psychology and the emergent mind/ Hove : BrunnerRoutledge, 230 p. - Book. 
5 Мелетинскии Е.М. Аналитическая психология и проблема происхождения архетипических сюжетов. Бессознательное: сборник / Е. М. Мелетинскии. - Новочеркасск, 1994. - 379 с.- Сборник научных статей.

6 Юнг К. Архетип и символ. М.: Ренессанс: 1991. 304 с. - Книга.

7 Русаков В.М. Категория концепт - архетип - дискурс: методологические новачии в исследовательском инструментарии современного гуманитарного знания Вестник Нижневартовского государственного университета. 2010. №2. 50-55 с. - Журнал.

8 Берсенева, О. Ю. Лингвориторическая организачия психолого-прагматического дискурса (на материале популярных книжных серий о достижении успеха): монография / А.А. Ворожбитова, О.Ю. Берсенева. - 2-е изд., стер. - М.: ФЛИНТА, 2014. - 197 с. -Монография.

9 Кшибеков, Д. К. Ментальная природа казаха /Д. К. Киибеков. - Алматы: Галым, 2005. - 72 с. - Книга.

10 Аюпов, Н. Г. Тенгрианство как открытое мировоззрение: монография / Н. Г. Аюпов. - Алмать:: КазНПУ им. Абая, 2012 - 256 с. - Монография.

11 Федорова Лена В. К вопросу идентичности концептов «язычества» славян, тенгринианства тюрков и монголов /Л. В. Федорова // Cопсогde. - 2016. - №1. - с. 72-88-Журнал.

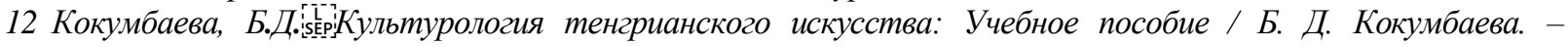
Павлодар: ПГПИ, 2012. - 156 с. - Учебное пособие.

13 Акатаи, С.-К. Н. Мировоззренческии синкретизм казахов: автореферат дисс. ... докт. филос. наук / С.-К. Н. Акатай. - Алматьі, 1995. - 38 с. - Автореферат.

14 Аргынбаев, Х. А. Брак и семья у казахов: автореферат дис. ... докт. ист. наук / Х. А. Аргынбаев. - АлмаAma: АН Каз.ССР, 1975. - 130 c. - Автореферат.

15 Каскабасов, С. А. Кольбель искусства / С. А. Каскабасов. - Алма-Ата: Онер, 1992. - 368 с. - Книга.

16 Древнетюркский словарь / В.М. Наделяев, Д. М. Насилов, Э. Р. Тенишев, А. М. Щербак. - Ленинград: Наука, Ленинградское отделение, 1969. - 677 с. - Словарь.

17 Мадигожин, Д. Т. Логика Небесного Закона. Көк Төре / Д. Т. Мадигожин, С. С. Аязбаев. - Алматы: Изд- во Apыc, 2012. - 168 c. - Книга.

18 Сарыбаева, М. Ш. Система обозначений родства в английском, русском и казахском языках: автореферат дисс. ... канд. филол. наук / М. Ш. Сарыбаева. - Алматы,, 1991. - 33 с. -Автореферат.

19 Севортян, Э. В. Этимологический словарь тюркских языков (общетюркские и межтюркские основы на гласные) /Э. В. Севортян. - М.: Издательство «Наука», 1974. - 767 с. - Словарь.

20 Сулейменов, О. О. Тюрки в доистории / О. О. Сулейменов. - Алмать:: Атамұра, 2002. - 320 с. - Книга.

21 Абуов, А. П. Религии в Казахстане: монография / А. П. Абуов, Е. М. Смагулов. - Костанай, ТОО “Костанайский печатный двор”, 2011. - 255 с. - Монография.

22 Kimmel M. Culture regained: situated and compound image schemas. // Hampe B (ed.) From Perception to Meaning: Image Schemas in Cognitive Linguistics, Berlin: Mouton de Gruyter. 2005. p. 285-311. -Book.

23 Желтоксан Ж. Ақ Сарбаз - Космический Воин. Алматы, 1993143 с. - Книга.

References:

1. Krasnyh V. V. Etnopsiholingvistika i lingvokülturologia: kurs leksǐ̌/V. V. Krasnyh. - M. : Gnozis, 2002. - 284 s. - Kurs leksi.

2. Stepanov Iu. S. Konstanty : slovär ruskoi kültury. M., 2001. 824 s. - Slovär.

3. Bölşakova A.İu. "Teoria arhetipa i konseptologia” Külturologicheski jurnal, no. 1, 2012, pp. 8. -

Külturologicheski jurnal.

4. Knox, Jean, 2003 Archetype, attachment, analysis: Jungian psychology and the emergent mind/ Hove :

Brunner-Routledge, 230 r. - Book.

5. Meletinskiü E.M. Analiticheskaia psihologia i problema proishojdenia arhetipicheskih süjetov.

Bessoznatelnoe: sbornik / E. M. Meletinskiu. - Novocherkassk, 1994. - 379 s.- Sbornik nauchnyh statei.

6. $\quad$ Iung K. Arhetip i simvol. M.: Renesans: 1991. 304 s. - Kniga.

7. Rusakov V.M. Kategoria konsept-arhetip-diskurs: metodologicheskie novasii v issledovatelskom

instrumentarii sovremennogo gumanitarnogo znania Vestnik Nijnevartovskogo gosudarstvennogo universiteta.

2010. №2. 50-55 s. - Jurnal.

8. Berseneva, O. İ. Lingvoritoricheskaia organizasia psihologo-pragmaticheskogo diskursa (na materiale populärnyh knijnyh seri o dostijenii uspeha): monografia / A.A. Vorojbitova, O.Iu. Berseneva. - 2-e izd., ster. - M.: FLINTA, 2014. - 197 s. -Monografia.

9. Kșibekov, D. K. Mentälnaia priroda kazaha / D. K. Kşibekov. - Almaty: Galym, 2005. - 72 s. - Kniga. 10

10. Aiupov, N. G. Tengrianstvo kak otkrytoe mirovozzrenie: monografia /N. G. Aiupov. - Almaty: KazNPU im.

Abaia, 2012 - 256 s. - Monografia.

11. Fedorova Lena V. K voprosu identichnosti konseptov «iazychestva» slavän, tengrinianstva türkov i mongolov /

L. V. Fedorova // Concorde. - 2016. - №1. - s. 72-88 - Jurnal.

12. Kokumbaeva, B.D.

Pavlodar: PGPI, 2012. - 156 s. - Uchebnoe posobie

13. Akată̌, S.-K. N. Mirovozzrencheskǐ sinkretizm kazahov: avtoreferat diss. ... dokt. filos. nauk / S. -K. N. Akatai.

- Almaty, 1995. - 38 s. - Avtoreferat. 
14. Argynbaev, X. A. Brak i semä u kazahov: avtoreferat dis. ... dokt. ist. nauk/H. A. Argynbaev. - Alma-Ata: AN Kaz.SSR, 1975. - 130 s. - Avtoreferat.

15. Kaskabasov, S. A. Kolybel iskustva / S. A. Kaskabasov. - Alma-Ata: Oner, 1992. - 368 s. -Kniga.

16. Drevnetürkski slovär /V.M. Nadeläev, D. M. Nasilov, E. R. Tenişev, A. M. Şerbak. - Leningrad: Nauka, Leningradskoe otdelenie, 1969. - 677 s. - Slovär.

17. Madigojin, D. T. Logika Nebesnogo Zakona. Kök Töre / D. T. Madigojin, S. S. Aiazbaev. -Almaty: İzd-vo Arys, 2012. - 168 s. - Kniga.

18. Sarybaeva, M. Ş. Sistema oboznacheni rodstva v angliskom, ruskom i kazahskom iazykah: avtoreferat diss. ... kand. filol. nauk / M. S.. Sarybaeva. - Almaty, 1991. - 33 s. -Avtoreferat.

19. Sevortän, E. V. Etimologicheski slovär türkskih iazykov (obşetürkskie i mejtürkskie osnovy na glasnye) / E. V. Sevortän. - M.: İzdatelstvo «Nauka», 1974. - 767 s. - Slovär.

20. Suleimenov, O. O. Türki v doistorii / O. O. Suleimenov. - Almaty: Atamūra, 2002. - 320 s. - Kniga

21. Abuov, A. P. Religii v Kazahstane: monografia /A. P. Abuov, E. M. Smagulov. - Kostanai, TOO "Kostanaiski pechatnyi dvor", 2011. - 255 s. - Monografia.

22. Kimmel M. Culture regained: situated and compound image schemas. // Hampe B (ed.) From Perception to

Meaning: Image Schemas in Cognitive Linguistics, Berlin: Mouton de Gruyter. 2005. r. 285-311. - Book.

23. Jeltoksan J. Aq Sarbaz - Kosmicheski Voin. Almaty, 1993143 s. - Kniga.

МРНТИ 378.02:37

https://doi.org/10.51889/2020-4.1728-7804.27

Мынбаева А.П., ${ }^{1}$ Кудасбекова А.Б. ${ }^{2}$

1,2 Оңтүстік Қазақсттан мемлекеттік педагогикальљқ университеті, Шымкент, Қазақстан

\title{
ЛИНГВИСТИКАЛЫК КЕНІСТІКТЕГІ МӘДЕНИ КОД ПЕН ТІЛДІК КОД
}

\author{
Анцатпа
}

Мәтін линвистикасы ілімі мен мәтін теориясы тығыз байланысты. Екеуінің нысаны бір бірімен ұштасып жатады. Мәтін теориясы мәтінді құрылымдық және қызметтік жақтарынан алып таңдайды. Құрылымдық тұрғыдан зерттегенде мәтін негізгі салаларға көңіл бөледі. Байланыстылығы - бұл мәтіннің дұрыс құрылуы, дұрыс құрылмауы деген мәселелермен ұштасады. Мұнда элементтері неден тұрады және олардың арасындағы байланыстың сипаты қандай? Оны нелер құрайды? деген сұраққа жауап алынады.

Оқушылардың жеке даму көрсеткіштерінің ішінде білім беру компонентін ерекше атап өту керек. Ол өзінің ұлттық мәдениетін терең меңгеру міндеттерімен және ана тілін еркін меңгерумен байланысты. Кейбір жағдайларда мәдени және тілдік код арасындағы түсініспеушіліктер адамдар арасындағы қарым-қатынасқа теріс әсер етуі мүмкін, сондықтан қазіргі уақытта көптеген ғалымдар мәдени және тілдік кодтардың өзара әсерін зерттеумен айналысады. Ұлттық мәдени код әдебиетте айқын көрінетіндіктен, мақала авторлары оны қазіргі мектепте оқыту әдістемесіне жүгінеді. Мақаланың жетекші идеясы Рухани жаңғыру міндеттерін жүзеге асыру үшін әдеби шығармалардың тәрбиелік әлеуетін анықтаумен байланысты.

Түйін сөздер: ілім, мәтін, лингвистикалық кеңістіктегі, мәдени код, тілдік код

Mynbayeva A., ${ }^{1}$ Kudasbekova $A^{2}$.

${ }^{1,2}$ South Kazakhstan State Pedagogical University, Shymkent, Kazakhstan

\section{CULTURAL CODE AND LANGUAGE IN LANGUAGE SPACE}

\section{Abstract}

Text linguistics is closely related to the teaching and theory of text. The shape of both is the same. The theory of the text selects the text from a structural and service side. In structural research, the text draws attention to the main areas. Connectedness is that it is correctly worded, incorrectly worded. What are the elements and what is the nature of the relationship between them? What does it do? it is taken to answer.

Among the indicators of personal development of students, it is especially important to distinguish an educational component. He is connected with the tasks of deep development of his national culture and free mastery of his native language. In some cases, misunderstandings between the cultural and linguistic code can have a negative impact on the 